\title{
ANALYSIS OF URBANIZATION IMPACT ON CHANGES IN RIVER DISCHARGE - A CASE STUDY OF THE BIAŁA RIVER CATCHMENT
}

\author{
JAROSŁAW CHORMAŃSKI \\ Department of Hydraulic Engineering, Warsaw University of Life Sciences, \\ Nowoursynowska 166, 02-787 Warsaw, Poland, e-mail: j.chormanski@levis.sggw.pl
}

\begin{abstract}
The article presents a simulation of urbanization impact on runoff changes in an urbanized catchment. Application of a distributed hydrological WetSpa model enabled comprehensive use of Landsat satellite images as a source of data about contemporary and historical land cover in the catchment. The analyses conducted for the Biała river catchment, with over $60 \%$ of the area being urbanized, revealed a significant influence of changes in the size of urbanized area on runoff hydrograph.
\end{abstract}

\section{INTRODUCTION}

Over half of the world's population live in urban areas nowadays and global trends suggest that this number will grow in the future (Martine [17]), taking on the character of a global change (Gutry-Korycka [12]). The rise in urban population is accompanied by an increase in urbanized area. One of the most important impacts of urbanization processes is the growing area of impervious (sealed) surfaces such as car parks, asphalt, concrete or gravel roads, or house roofs, which prevent rainwater infiltration into the soil and cause its direct runoff to storm drain systems (Geiger and Dreiseitl [10], Tourbier and Westmacott [25], Gutry-Korycka [13]).

A lot of possibilities of monitoring environmental changes, including the progress of urbanization, have appeared with remote sensing techniques. A particularly useful source of data are satellite images from the Landsat program (NASA Landsat Program, 1972-2011, [18]), whose historical database goes back to the late 1970s. The proper application of this data source enables identifying types of land use or cover and their changes both in time and space. This type of analysis was used to define changes in CN coefficient in the period 1973-2000 for Kenya (Olang et al. [21]), and to correlate the impact of land cover changes on the maximum flood levels (Olang and Fürst [20]). Zhang et al. [29] used similar methodology to identify the causes of changes occurring in protected wetlands. A broader analysis of the influence of land use changes on hydrological processes was conducted by Cruise et al. [8] in the southern states of the USA, but they did not obtain direct statistical correlations. This article presents a possibility of employing distributed hydrological model WetSpa (Liu et al. [15]) and data from the Landsat archives for simulating contemporary and historical runoff hydrographs in urban catchment conditions, exemplified by research conducted in the city of Białystok (the Biała river catch- 
ment). Simulation results were compared and assessed in terms of urbanization impact on changes in hydrological characteristics.

\section{RESEARCH AREA}

The area chosen for the research was the catchment of the river Biała, a left-bank tributary of the Supraśl and the main river flowing through the city of Białystok. The area of the catchment is c. $133 \mathrm{~km}^{2}$. The river has its source near the village of Prostki at the elevation of c. $168 \mathrm{~m}$ a.s.1. and it flows into the Supraśl at $115 \mathrm{~m}$ a.s.l. The river flows in the north-western direction and it has a uniform drainage pattern. The river crosses an urbanized area which is why both the watercourse and its valley have been heavily modified. More than $60 \%$ of the river catchment lies in the area of the city of Białystok (Tyszewski et al. [26]). The rainwater drainage system supplements, and to a large extent substitutes, the natural surface drainage. In the city area there are 22 large drainage outfalls. Urbanization in the Biała catchment was particularly intensive in the late 1970s, which is confirmed by the change in the population of Białystok. In this article, the author has attempted to demonstrate how changes in the population and the area of a city are reflected in runoff changes.

\section{METHODOLOGY}

\subsection{HYDROLOGIC MODEL}

The hydrologic model WetSpa - Water and Energy Transfer between Soil, Plant and Atmosphere, originally developed as a steady state water balance model (Batelaan et al. [2], Wang et al. [27]), is nowadays used for dynamic calculations of catchment runoff (De Smedt et al. [24]). WetSpa consists of two modules: a GIS module facilitating determination of spatial distribution of local parameters and developing result maps, and the hydrological module. The GIS interface, developed as a module of ArcGIS 10 software, is equipped with a set of functions enabling determination of spatial parameters, activating particular hydrologic models and analysing the obtained results (Chormański and Michałowski [5]). The hydrologic module comprises two computational methods: distributed and semi-distributed (discrete) parameter models. Wetspa model has been used in Poland for simulating runoff from agricultural catchments (Porretta-Brandyk et al. [22], [23], Chormański and Batelaan [4]) and an urban catchment (Berezowski et al. [3], Chormański et al. [6]). The research presented used a distributed parameter model, where calculations are performed in a grid of raster elements (GRID). Based on digital raster maps (a Digital Elevation Model, a land use map and a soil map), each grid node is assigned spatial parameters dependent on soil type, land use and relief. A detailed 
description of the functions used in the model was provided by Liu [16] and Porretta-Brandyk (et al. [22]).

Each raster/grid cell of the model is treated as a set of four horizontal layers: zones of canopy, roots, soil aeration and aquifer saturation. In each of them, hydrological processes are simulated in the order corresponding to that of the natural water cycle: precipitation, interception by vegetation, infiltration, surface (depression) storage, surface runoff, interflow, percolation and groundwater flow. A land use map of the catchment is used to calculate vegetation parameters: the maximum $\left(I C_{\max }\right)$ and minimum $\left(I C_{\min }\right)$ interception storage capacity, $V D$ - vegetation density and $R D$ - root depth, as well as $n$ - Manning roughness coefficient. In the aeration and saturation zones, hydraulic conductivity $(K s)$ and parameters of soil water retention curves are determined, $\theta_{s}$ - overall porosity, $\theta_{f}$ - field capacity, $\theta_{t w}$ - permanent wilting point, $\theta_{r}$ - residual moisture, $B$ - pore size distribution index), based on soil texture characteristics assigned according to soil type.

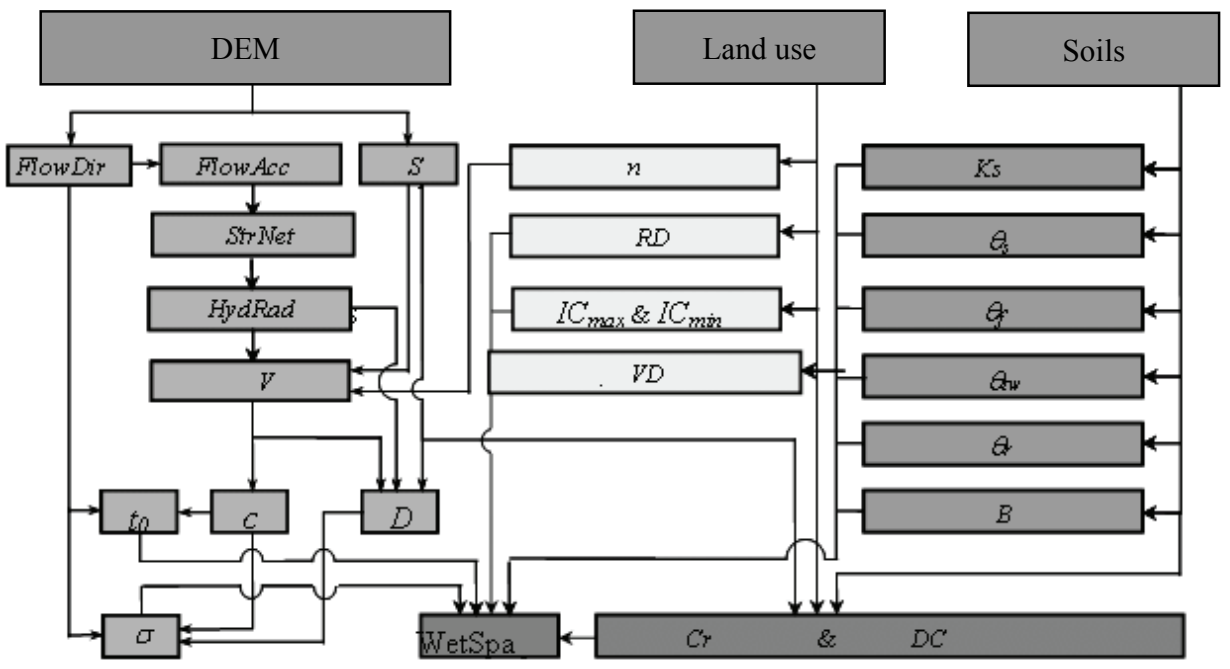

Fig. 1. The calculation scheme of spatially distributed physical parameters in a catchment based on digital maps (adapted from Liu [16])

Digital Elevation Model (DEM) is used for calculating runoff parameters based on the following maps: S - slopes; FlowDir - direct flow directions, FlowAcc - flow accumulation, StrNet - model stream network, HydRad - hydraulic radius of streams, and $\mathrm{V}$ - mean flow velocity. The latter one uses surface roughness parameter in the form of a Manning coefficient map. The FlowAcc map and the StrNet developed from it are used to determine elementary catchments for the catchment size assigned by the user. In the next stage, they are used to determine unit hydrograph parameters $\left(t_{0}-\right.$ mean time of inflow from a raster cell to the outfall and $\sigma$-standard deviation of in- 
flow time (equations (4) and (5)), which are numerical approximation of diffusion wave parameters $(c, D)$. All the three basic maps are used to calculate elementary raster depression storage maps (DC) and the runoff coefficient map (Cr) (Liu [16]). Based on the parameter maps, a dynamic water balance is calculated in each of the four layers of the model grid cells. Hydrological processes are modelled by using physical and empirical functions. The crucial factor responsible for the shape of surface runoff and interflow is soil moisture in the root zone. Defining this moisture for every catchment cell is based on the following water balance equation for the surface layer of soil

$$
D \frac{\Delta \theta}{\Delta t}=P-I-S-E-F-R,
$$

where:

$D$ - root zone depth,

$\Delta \theta$ - change in soil moisture,

$\Delta t$ - time step,

$P$ - precipitation,

I - initial loss including interception and depression storage,

$S$ - surface runoff,

$E$ - evapotranspiration,

$F$ - interflow,

$R$ - percolation from root zone.

Interception volume is calculated from the equation

$$
I_{i}=I_{i, \min }+\left(I_{i \cdot \max }-I_{i \cdot \min }\right)\left[\frac{1}{2}+\frac{1}{2} \sin \left(2 \pi \frac{d-87}{365}\right)\right]^{b}
$$

where:

$I_{i, \min }-$ minimum interception for a particular cell [mm],

$I_{i, \max }-$ maximum interception for a particular cell $[\mathrm{mm}]$,

$d$ - day of a year,

$b \quad$ - local parameter.

Effective precipitation $(S)$ is calculated by using a modified rational formula dependent on soil moisture and runoff coefficient

$$
S=C_{r} P_{n}\left(\theta / \theta_{s}\right),
$$

where:

$S$ - effective precipitation,

$C_{r}-$ runoff coefficient dependent on terrain slope, soil type and catchment use,

$P_{n}-$ precipitation volume after subtracting water retained by vegetation interception,

$\Theta-$ actual soil moisture,

$\Theta_{s}-$ maximum soil water storage capacity. 
The effective precipitation calculated in this way fills depression storage first and is then removed as surface runoff, which is calculated from a simplified diffusion wave equation. The numerical approximation of the diffusion wave equation (De Smedt et al. [24]) as an instantaneous unit hydrograph (IUH) enables defining runoff at the end of its flow path as a function of the mean flow time from a given raster cell and standard deviation of flow time to the outlet

$$
\begin{gathered}
U(t)=\frac{1}{\sigma \sqrt{2 \pi t^{3} / t_{0}^{3}}} \exp \left[\frac{-\left(t-t_{0}\right)^{2}}{2 \sigma^{2} t / t_{0}}\right], \\
Q(t)=\int_{A}^{t} \int_{0}^{t} Q_{0}(\tau) U(t-\tau) d \tau d A,
\end{gathered}
$$

where:

$u(t)$ - unit hydrograph function for a particular flow path $\left(\mathrm{s}^{-1}\right)$,

$t_{0}-$ mean flow time (s),

$\sigma \quad-$ standard deviation of flow time (s),

$Q(t)-$ runoff hydrograph $\left(\mathrm{m}^{3} / \mathrm{s}\right)$,

$Q_{0}$ - effective precipitation $\left(\mathrm{m}^{3} / \mathrm{s}\right)$,

$\tau$ - time delay (s),

$t$ - time (s),

$A \quad$ - catchment surface area $\left(\mathrm{km}^{2}\right)$.

Interflows are estimated for every cell using Darcy's law according to equations (6) and (7)

$$
\begin{gathered}
F=C_{e} D S_{0} K(\theta) / W, \\
R=K(\theta)=K_{s}\left(\frac{\theta-\theta_{r}}{\theta_{s}-\theta_{r}}\right)^{(2+3 B) / B},
\end{gathered}
$$

where:

$F \quad-$ interflow,

$R \quad-$ percolation from root zone,

$D$ - root zone depth,

$C_{e} \quad$ - scale parameter dependent on land use,

$S_{0} \quad-$ terrain slope,

$K(\Theta)$ - hydraulic conductivity in unsaturated zone,

$K_{s}$ - hydraulic conductivity in saturated zone,

$\Theta_{r} \quad$ - residual soil moisture,

$W \quad$ - size of raster cell,

$B \quad-$ soil pore size distribution index. 
Calculations of groundwater flow in WetSpa model are performed in the subcatchment with the use of a semi-distributed model assuming non-linearity between groundwater flow and storage (Wittenberg and Sivapalan [28])

$$
Q_{g}=C_{g} S_{g}^{2}
$$

where:

$Q_{g}-$ groundwater flow from a subcatchment,

$C_{g}$ - non-linear reservoir recession coefficient,

$S_{g}-$ groundwater storage.

The total flow from a catchment is calculated at the outfall as the sum of surface runoff, interflow and groundwater flow.

\subsection{ASSESSMENT OF THE QUALITY OF MODEL OPERATION}

The quality of simulations performed is assessed by calculating statistical measures of model correctness: ME $\left[\mathrm{m}^{3} / \mathrm{s}\right]$, MAE $\left[\mathrm{m}^{3} / \mathrm{s}\right]$ and NS $[-]$. Measure ME is the mean difference between the predicted and the observed runoff, reflecting the possibility of reconstructing the elements of water balance. The best possible ME value is 0 , which accounts for the perfect reconstruction of the observed runoff by the model (equation (9)).

$$
M E=\frac{\sum_{i=1}^{N}\left(Q s_{i}-Q o_{i}\right)}{N}
$$

where:

$Q s_{i}$ - values of simulated runoff,

$Q o_{i}$ - values of observed runoff,

$N$ - number of time steps.

Correctness measure MAE (equation (10)) demonstrated mean error expressed in discharge units

$$
M A E=\frac{\sum_{i=1}^{N}\left|Q s_{i}-Q o_{i}\right|}{N} .
$$

Model correctness measure NS (equation (11)) is the Nash-Sutcliffe coefficient [19], which is a modified version of determination coefficient that is insensitive to the heteroscedasticity of discharge determination errors. It describes the correctness of the simulated runoff along the drainage system. NS values vary from negative ones to 1 , where 1 is the best value. 


$$
N S=\frac{\sum_{i=1}^{N}\left(Q o_{i}-Q s_{i}\right)^{2}}{\sum_{i=1}^{N}\left(Q o_{i}-\bar{Q} o\right)^{2}} .
$$

Global parameters were calibrated semi-automatically with the use of PEST program algorithms (Doherty et al. [9]). These parameters enable reproducing general hydrological conditions in the catchment: initial soil moisture, groundwater table depth, groundwater flow recession curve, proportion of surface runoff, interflow and groundwater flow in the total runoff and parameters characterizing snow melting processes.

\subsection{HYDROMETEOROLOGICAL DATA}

In the research, a 6-hour temperature and precipitation data sequences for Białystok were used obtained from NOAA National Data Center [30] (http: //lwf.ncdc.noaa.gov/ oa/ncdc.html). Potential evapotranspiration (PET) data, calculated with PenmanMonteith formula (Allen [1]), were based on data from the Warsaw University of Life Sciences weather station in Nowy Lipsk, c. $80 \mathrm{~km}$ north of the research area. 24-hour PET values were then converted to the 6-hour simulation interval of the model following the proportion: $10 \%$ of the 24 -hour PET value was assigned to the period between $0: 00$ to $6: 00 ; 40 \%$ - to the $7: 00-12: 00$ period, $40 \%$ - to $13: 00-18: 00$ and $10 \%$ - to the 19:00-24:00 period. Six-hour discharge values were based on water levels measured with Diver instrument at 20-minute intervals and then aggregated to a 6-hour modelling step (Tyszewski et al. [26]). The calculations employed a rating curve based on 18 hydrometric measurements taken in 2008-2010 at a measurement station in Zawady.

\subsection{DIGITAL MAPS}

The spatial (local) parameters of the model were estimated from the following information layers: a $1: 25000$ agricultural soil map developed at the Institute of Soil Science and Plant Cultivation in Puławy, a Digital Elevation Model (DEM) developed by contour line interpolation from 1:10 000 topographic maps, and land use maps for the years 1977, 1992 and 2007 based on satellite images from the Landsat Programme. The adopted size of calculation cell in the raster data model was $25 \mathrm{~m}$. The DEM used for determining potential paths of water runoff from the catchment and surface runoff directions was modified by burning the river drainage network and the storm drainage network 2 metres into it. This enabled introducing the actual flow directions, which are not always consistent with terrain slope in urban environment. Due to the fact that 
urban areas lack information about soil type on soil maps, averaged filtration parameters were adopted for them.

\subsection{SATELLITE IMAGES AND CLASSIFICATION}

The analysis employed 3 satellite images from the Landsat Programme archive recorded at 15-year intervals in August: a Landsat 2 MSS image from 7th August 1977, a Landsat 4 TM image from 30th August 1992 and a Landsat 5 TM image from 16th August 2007. In order to develop land use maps for the years analysed, supervised image classification using the maximum likelihood method was conducted and its results were later generalized. Error matrix demonstrated very high agreement of classification results with the type of land cover identified in the following classes: built-up areas, meadows and pastures; arable land, water bodies, broadleaf forests and coniferous forests. The overall accuracy reached $97.5 \%, 98.0 \%$ and $98.5 \%$ for the images from 1977, 1992 and 2007, respectively, and the values of kappa coefficient were close to zero, which enabled evaluating classification results as very good (Kazubski [14]).

The results of supervised classification were adapted to the structure and spatial resolution of the hydrological model, and also adjusted to the classes of the model land use map. In the subsequent analytical process, the delineated urbanized areas were modified, by adopting a variable degree of terrain surface sealing on raster cell scale, in line with the methodology proposed by Chormański et al. [7]. The 2007 image was acknowledged as representative of the city development in the simulation period. For that year, the adopted sealing of impervious terrain was expressed as a proportion defined from classification of a VHR (very high spatial resolution) satellite image from Ikonos sensor, with a $1 \mathrm{~m}$ pixel resolution (Berezowski et al. [3]). Terrain sealing determined in this way, and used in the distributed model, produces better results of precipitation-induced flood simulations for an urban catchment than sealing determined from lower pixel resolution images, e.g., Landsat $-30 \mathrm{~m}$ (Berezowski et al. [3]).

Due to the varying spatial resolution of historical data from Landsat satellite (1992 $-30 \mathrm{~m} ; 1977-60 \mathrm{~m}$ ) and the absence of field measurements (or high-resolution pictures) for the analysed historical images, a similar sealing degree distribution (from a VHR image classification) was adopted in urban pixels common for both historical images and the contemporary image (2007).

\section{RESULTS}

\subsection{LAND USE CHANGES}

The results of land use change analysis indicate that significant land cover changes in the Biała catchment in 1977-2007 took place chiefly in two classes (Table 1): built- 
up area and agricultural area. In 1977, built-up area accounted for $20 \%$ of the catchment area, in $1992-40 \%$, and in $2007-46 \%$. For the first 15 years of the period, Białystok developed practically in all directions but the biggest changes occurred south and west of the city centre. Outside the city area, a growth in urbanized area was observed at the south-eastern edges of the Biała catchment. Differences in the extent of urban area in 1992 and 2007 are not big, one can observe urban sprawl chiefly in the north-western and western directions. The urbanized area in 1977 and the growths in built-up area after the next 15 and 30 years are shown in Fig. 2 . The city growth

Table 1

Proportion of land-cover classes in the Biała catchment in 1977, 1992 and 2007

\begin{tabular}{|l|c|c|c|}
\hline \multirow{2}{*}{\multicolumn{1}{|c|}{ Class }} & \multicolumn{3}{c|}{ Proportion of the catchment area [\%] } \\
\cline { 2 - 4 } & 1977 (MSS) & $1992(\mathrm{TM})$ & $2007(\mathrm{TM})$ \\
\hline $\begin{array}{l}\text { Agricultural areas: meadows, } \\
\text { pasture, arable land }\end{array}$ & 66 & 47 & 41 \\
\hline Water bodies & 1 & 1 & 1 \\
\hline Urbanized area & 20 & 40 & 46 \\
\hline Forests & 13 & 12 & 12 \\
\hline
\end{tabular}

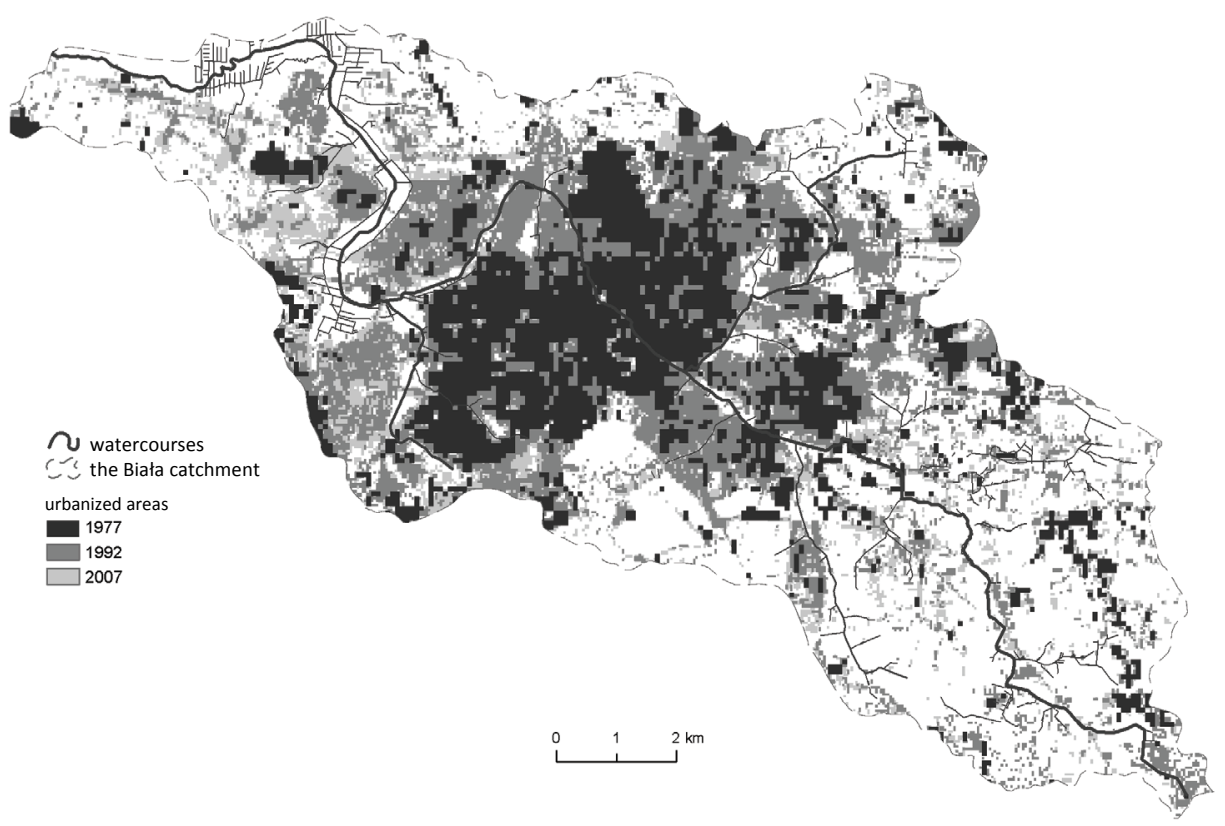

Fig. 2. Extent of urban area in the Biała catchment in 1977, 1992 and 2007 (adapted from Kazubski [14]) 
took place at the cost of agricultural area. In 1977, agricultural area accounted for $66 \%$ of the catchment area, 15 years later - only $47 \%$, and after the next 15 years $-41 \%$. The remaining land cover classes did not undergo significant changes with time. The proportion of water bodies was smaller than $1 \%$ in each image, while the area of forests ranged between $12-13 \%$ (Table 1).

The growth in urbanized area in the Biała catchment is reflected by demographic changes. In 1977, Białystok had 207416 residents (Central Statistical Office [11]) and till 1992 the population grew by 66679 to reach 274095 (Central Statistical Office [11]). This means a growth by more than $32 \%$ over the analysed 15 years. On the other hand, population growth in 1992-2007 was not so significant. In 2007, the city had 294143 residents (Central Statistical Office [11]), i.e. 20048 more than fifteen years earlier, which accounts for a mere $7 \%$ growth.

\subsection{HYDROLOGICAL MODELLING}

In order to demonstrate the influence of urbanization on the runoff volume from a catchment, the author used a WetSpa model developed for the Biała catchment (Berezowski et al. [3]). It was calibrated and verified for a short period of floods in the range NWQ-WWQ (low high discharge - very high discharge). Model simulations were carried out for the measurement station at Zawady between 11th May 2009 and 5th June 2009 (calibration) and from 5th June 2009 to 1st July 2009 (verification). Statistical model quality measures for the verification period assumed the values: $M E$ $=0.13 \mathrm{~m}^{3} / \mathrm{s} ; M A E=0.69 \mathrm{~m}^{3} / \mathrm{s} ; N S=0.49$. A visual comparison of hydrographs from the calibration and verification stages is shown in Fig. 3. The statistical measures of

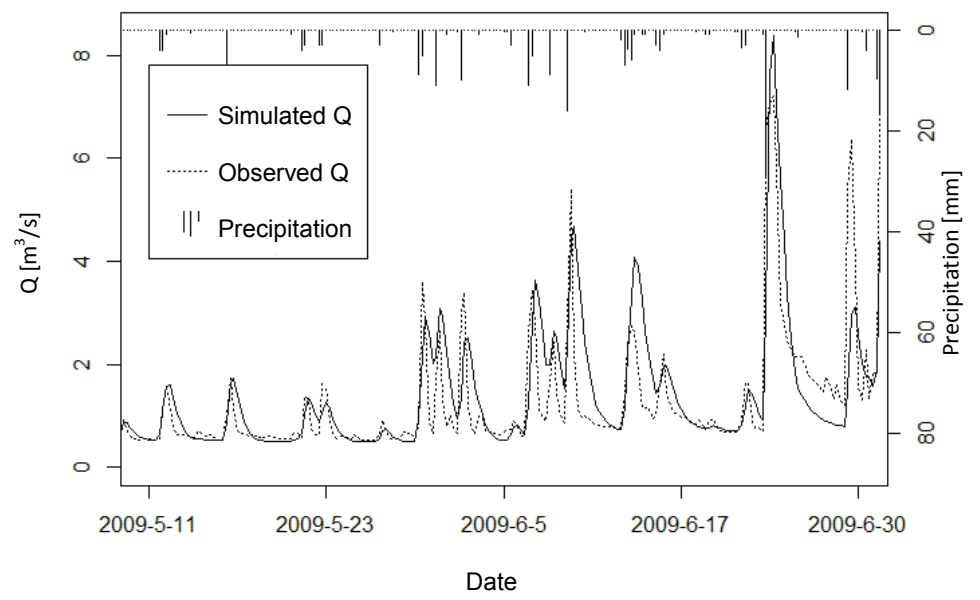

Fig. 3. Observed and calculated discharges in the river Biała at Zawady station at calibration and verification stages. Precipitation in 6-hour intervals 
model correctness enable autonomous assessment of model quality. The obtained values allow regarding calibration results as satisfactory. The analysis of runoff hydrographs demonstrates that the model reconstructs very well both the moment and the discharge of most floods and low-water periods. The few discrepancies may be interpreted as a consequence of the absence of spatial precipitation distribution in the catchment (only one precipitation station). Worse results were obtained while comparing the observed and the simulated flood wave recession curves, which is largely responsible for the relatively low values of the statistical measures of model quality.

Table 2

Hydrological statistics in particular years of historical analysis calculated for the periods shown in Fig. 3

\begin{tabular}{|c|c|c|c|c|c|}
\hline Year & $\begin{array}{c}\text { Low discharge } \\
{\left[\mathrm{m}^{3} / \mathrm{s}\right]}\end{array}$ & $\begin{array}{c}W Q \\
\text { High discharge } \\
{\left[\mathrm{m}^{3} / \mathrm{s}\right]}\end{array}$ & $\begin{array}{c}S Q \\
\text { Medium discharge } \\
{\left[\mathrm{m}^{3} / \mathrm{s}\right]}\end{array}$ & $\begin{array}{c}\text { Mean discharge } \\
>S Q \\
{\left[\mathrm{~m}^{3} / \mathrm{s}\right]}\end{array}$ & $\begin{array}{c}\text { Mean discharge } \\
<S Q \\
{\left[\mathrm{~m}^{3} / \mathrm{s}\right]}\end{array}$ \\
\hline 1977 & 0.52 & 6.48 & 1.19 & 2.29 & 0.70 \\
\hline 1992 & 0.50 & 8.09 & 1.21 & 2.44 & 0.69 \\
\hline 2007 & 0.50 & 8.39 & 1.23 & 2.51 & 0.69 \\
\hline
\end{tabular}

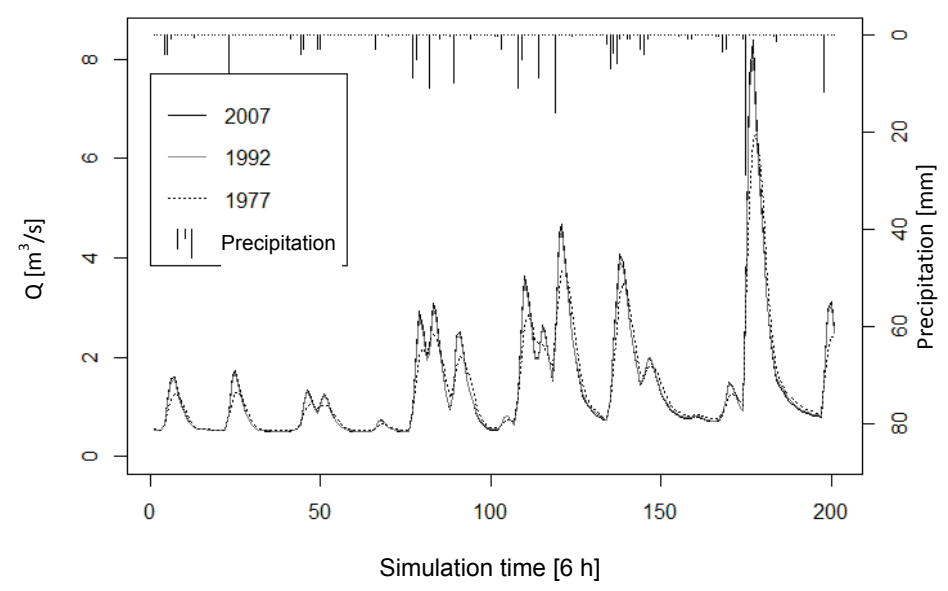

Fig. 4. Simulated discharges in the river Biała at Zawady station for different development stages of Białystok. Precipitation in 6-hour intervals

Subsequently, model parameters defined at calibration stage were used to perform a simulation for the same period of time, but with changed maps of local parameters based on satellite images from 1977 and 1992. The results of particular simulations for the three periods of city growth are shown in Fig. 4. Figure 5 presents the summary hydrograph of groundwater flow and interflow. Table 2 contains a comparison of basic hydrological statistics. Both the comparison of statistical data calculated from dis- 
charge simulation and the hydrograph shapes demonstrate a rise in high water levels and a fall in low water levels accompanying the advancing urbanization. What is more, urbanization development is accompanied by changes in runoff structure - the proportions of groundwater flow and interflow decrease significantly.

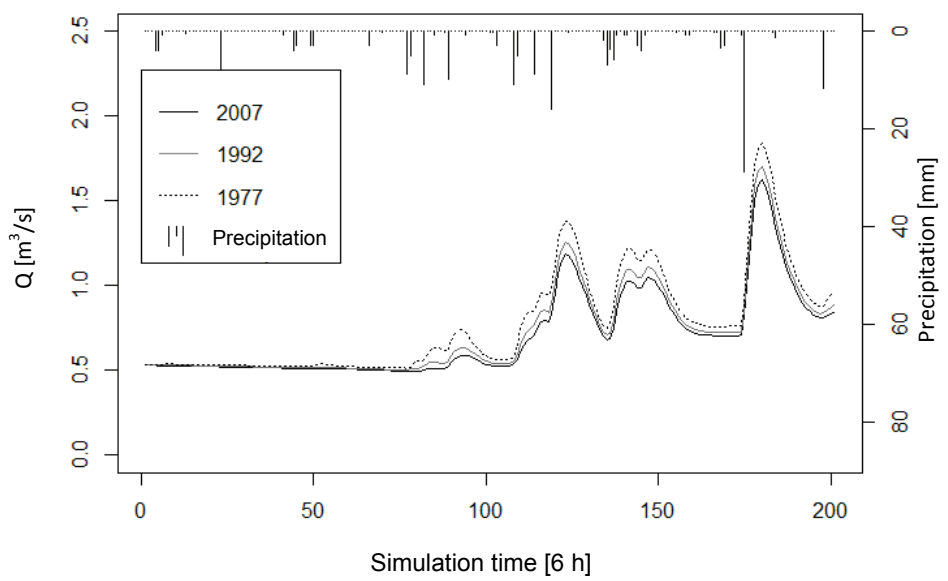

Fig. 5. Simulated groundwater-induced discharge in the river Biała at Zawady at different development stages of Białystok city. Precipitation in 6-hour intervals

\section{SUMMARY AND CONCLUSIONS}

The use of remote sensing methods has enabled accurate elaboration of contemporary and historical maps of land cover, which have allowed observing the changing extent of urban area in the Biała catchment. The obtained results are reflected in population size changes in the city of Białystok, whose 30\% growth in 1977-1992 brought about a 100\% rise in the size of urban area. Analysing satellite images enabled defining spatial parameters of a hydrological model of the catchment. The experiments demonstrated the validity of WetSpa model for simulating runoff from a catchment with a large proportion of urban areas. Thanks to spatial distribution of modelling parameters, the model is capable of performing accurate simulations of both the size and the time of a flood peak. It should be noted that only a model with fully distributed parameters enables a comprehensive use of information from satellite images. The obtained simulation results demonstrated a significant influence of urbanization processes on runoff volume from the Biała catchment. The 1977 scenario showed the maximum WQ discharge to be lower by $23 \%$ than real-time discharges, while the values obtained in the 1992 scenario were slightly lower (by 4\%) than those from contemporary observations. The simulation results also pointed to a significant change in the structure of runoff from the catchment, where a rise in the total runoff is accompanied by a decreased value of groundwater flow and interflow. 


\section{ACKNOWLEDGEMENTS}

The research was financed from a grant from the Ministry of Science and Higher Education of the Republic of Poland No. 637/N-Rosja/09/2010.

\section{REFERENCES}

[1] Allen R.G., Pereira L.S., Raes D., Smith M., Crop Evapotranspiration. Guidelines for Computing Crop Water Requirements, Vol. 56, Food and Agriculture Organization of the United Nations, 1998.

[2] Batelaan O., Wang Z.M., De Smedt F., An adaptive GIS toolbox for hydrological modeling, [in:] K. Kovar, H.P. Nachtnebel, (eds.), Application of geographic information systems in hydrology and water resources management, IAHS Publ., No. 235, 1996.

[3] Berezowski T., Chormański J., BatelaAn O., Canters F., Van De Voorde T., Impact of remotely sensed land-cover proportions on urban runoff prediction, International Journal of Applied Earth Observation and Geoinformation, 2012, 16, 54-65.

[4] Chormański J., BatelaAn O., Application of the WetSpa distributed hydrological model for catchment with significant contribution of organic soil. Upper Biebrza case study, Annals of Warsaw University of Life Sciences, SGGW Land Reclamation, 2011, 43(1), 25-35.

[5] ChORMAŃSKi J., MichaŁowski R., Model hydrologiczny zlewni Wet-Spa zintegrowany z modułem obliczeniowym $w$ środowisku ArcGIS, Przegląd Naukowy Inżynieria i Kształtowanie Środowiska, 2011, Vol. 20(3), 196-206

[6] Chormański J., PusŁowska-Tyszewska D., Kardel I., MirosŁaw-Świątek D., OKruszko T., Model zlewni o parametrach przestrzennych dyskretnie rozłożonych $w$ obszarze zurbanizowanym, Przegląd Naukowy Inżynieria i Kształtowanie Środowiska, 2012, Vol. 21, Issue 1(55), $3-17$.

[7] Chormański J., Van De Voorde T., De Roeck T., Batelaan O., Canters F., Improving Distributed Runoff Prediction in Urbanized Catchments with Remote Sensing based Estimates of Impervious Surface Cover, Sensors, 2008, 8, 910-932

[8] CRuise J.F., LAYMON C.A., Al-Hamdan O.Z., Impact of 20 Years of Land-Cover Change on the Hydrology of Streams in the Southeastern United States, Journal of the American Water Resources Association, 2010, 46, 1159-1170.

[9] DOHERTy J., BrebBer L., Whyte P., PEST: model independent parameter estimation. User manual, Watermark Computing Trademarks, Australia, 1994.

[10] GeIGer W., Dreiseitl H., Nowe sposoby odprowadzania wód deszczowych, Oficyna Wyd. ProjprzemEKO, Bydgoszcz 1999.

[11] GUS, 2011, Baza Danych Glównego Urzędu Statystycznego, stan na rok 2011, http://www.stat.gov.pl/gus

[12] GUTRY-KorycKa M., Urbanization in the global change development syndrome, Global Change, $2005,12,7-21$.

[13] Gutry-Korycka M., Odplyw ze zlewni zurbanizowanych, Prace i Studia Geograficzne, 2007, 38, $37-56$.

[14] KAZUBSKI O., Wptyw urbanizacji na zmiany odplywu w zlewni rzeki Białej, manuskrypt pracy magisterskiej, SGGW, Warszawa 2011.

[15] Liu Y.B., Gebremeskel S., De Smedt F., Pfister L., Flood prediction with the WetSpa model on a catchment scale, [in:] B.S. Wu, Z.Y. Wang, G.Q. Wang, G.H. Huang, H.W. Fang, J.C. Huang, (eds.), Flood Defence, Science Press, New York 2002. 
[16] LIU Y.B., Development and application of a GIS-based hydrological model for flood prediction and watershed management, Vrije Universiteit Brussel Press, Brussel, 2004, 315.

[17] Martine G., The State of the World Population 2007. United Nation Population Fund, New York 2007.

[18] NASA Landsat Program, 1972-2011: ETM+, TM, MSS scenes, USGS, Sioux Falls.

[19] NASH J., Sutcliffe J., River flow forecasting through conceptual models, Part 1. A discussion of principles, J. Hydrol., 1970, 10, 282-290.

[20] OlANG L.O., FÜRST J., Effects of land cover change on flood peak discharges and runoff volumes: model estimates for the Nyando River Basin, Kenya, Hydrol. Process, 2010, 25, 80-89.

[21] Olang L., Kundu P., BAuer T., FÜRST J., Analysis of spatio-temporal land cover changes for hydrological impact assessment within the Nyando River Basin of Kenya, Environmental Monitoring and Assessment, 2011, 179, 389-401

[22] Porretta-Brandyk L., Chormański J., Ignar S., Okruszko T., Brandyk A., Szymczak T., KRĘŻAEE K., Evaluation and verification of the WetSpa model based on selected rural catchments in Poland, J. Water and Land Development, 2010, 14, 115-133.

[23] Porretta-Brandyk L., Chormański J., Okruszko T., Brandyk A., Automatic calibration of the WetSpa distributed hydrological model for small lowland catchments, [in:] M. Świątek, T. Okruszko (eds.), Modelling of Hydrological Processes in the Narew Catchment, Geoplanet: Earth and Planetary Sciences, Springer-Verlag, Berlin, Heidelberg, 2011, 43-62.

[24] De Smedt F., LiU Y.B., Gebremeskel S., Hydrologic modeling on a catchment scale using GIS and remote sensed land use information, [in:] Risk Analysis II, C.A. Brebbia (ed.), WTI Press, Southampton, Boston, 2000, 295-304.

[25] TOURBIER J.T., WeSTMACOTt R., Water resources protection technology, US EPA, 1981.

[26] Tyszewski S., Kardel I., PusŁowska-Tyszewska D., Okruszko T., Stańczyk T., Oglecki P., Chormański J., MirosŁaw-ŚwiąteK D., MichaŁowski R., PolaK W., Studium hydrograficzne doliny rzeki Biatej z wytycznymi do zagospodarowania rekreacyjno-wypoczynkowego i elementami matej retencji oraz prace hydrologiczne niezbędne do sporzqdzenia dokumentacji hydrologicznej, Warszawa 2009.

[27] Wang Z.M., BatelaAn O., De Smedt F., A distributed model for water and energy transfer between soil, plants and atmosphere (WetSpa), Phys. Chem. Earth, 1996, 21(3), 189-193.

[28] Wittenberg H., Sivapalan M., Watershed groundwater balance estimation using streamflow recession analysis and baseflow separation, J. Hydrol., 1999, 219, 20-33.

[29] Zhang S., Na X., Kong B., Wang Z., Jiang H., Yu H., Zhao Z., Li X., Liu C., Dale P., Identifying Wetland Change in China's Sanjiang Plain Using Remote Sensing Wetlands, Wetlands, 2009, 29, 302-313.

[30] http://lwf.ncdc.noaa.gov/oa/ncdc.html 